\title{
Glutamate and Amyloid $\beta$-Protein Rapidly Inhibit Fast Axonal Transport in Cultured Rat Hippocampal Neurons by Different Mechanisms
}

\author{
Hiromi Hiruma, ${ }^{1}$ Takashi Katakura, ${ }^{1}$ Sanae Takahashi, ${ }^{1}$ Takafumi Ichikawa, ${ }^{2}$ and Tadashi Kawakami ${ }^{1}$ \\ Departments of ${ }^{1}$ Physiology and ${ }^{2 B i o c h e m i s t r y, ~ K i t a s a t o ~ U n i v e r s i t y ~ S c h o o l ~ o f ~ M e d i c i n e, ~ S a g a m i h a r a ~ 228-8555, ~ J a p a n ~}$
}

\begin{abstract}
Impairment of axonal transport leads to neurodegeneration and synapse loss. Glutamate and amyloid $\beta$-protein $(\mathrm{A} \beta)$ have critical roles in the pathogenesis of Alzheimer's disease (AD). Here we show that both agents rapidly inhibit fast axonal transport in cultured rat hippocampal neurons. The effect of glutamate $(100 \mu \mathrm{M})$, but not of $\mathrm{A} \beta_{25-35}(20 \mu \mathrm{M})$, was reversible, was mimicked by NMDA or AMPA, and was blocked by NMDA and AMPA antagonists and by removal of extracellular $\mathrm{Ca}^{2+}$. The effect of $\mathrm{A} \beta_{25-35}$ was progressive and irreversible, was prevented by the actin-depolymerizing agent latrunculin $B$, and was mimicked by the actin-polymerizing agent jasplakinolide. $A \beta_{25-35}$ induced intracellular actin aggregation, which was prevented by latrunculin $B$. $A \beta_{31-35}$ but not $A \beta_{15-20}$ exerted effects similar to those of $\mathrm{A} \beta_{25-35}$. Full-length $\mathrm{A} \beta_{1-42}$ incubated for $7 \mathrm{~d}$, which specifically contained 30-100 kDa molecular weight assemblies, also caused an inhibition of axonal transport associated with intracellular actin aggregation, whereas freshly dissolved $\mathrm{A} \beta_{1-40}$, incubated $\mathrm{A} \beta_{1-40}$, and fresh $\mathrm{A} \beta_{1-42}$ had no effect. These results suggest that glutamate inhibits axonal transport via activation of NMDA and AMPA receptors and $\mathrm{Ca}^{2+}$ influx, whereas $\mathrm{A} \beta$ exerts its inhibitory effect via actin polymerization and aggregation. The ability of $A \beta$ to inhibit axonal transport seems to require active amino acid residues, which is probably present in the 31-35 sequence. Fulllength $\mathrm{A} \beta$ may be effective when it represents a structure in which these active residues can access the cell membrane. Our results may provide insight into the early pathogenetic mechanisms of AD.
\end{abstract}

Key words: axonal transport; glutamate; amyloid $\beta$-protein; actin; $\mathrm{Ca}^{2+}$; cultured hippocampal neurons

\section{Introduction}

Impairment of axonal transport leads to neuronal degeneration (Moretto and Sabri, 1988; Yonekawa et al., 1998), and thus it may be an early event in the pathogenesis of some neurodegenerative diseases (Brimijoin, 1982; Warita et al., 1999; Williamson and Cleveland, 1999). In Alzheimer's disease (AD) as well as other dementing disorders, a widespread loss of synapses occurs in the brain, and synaptic injury is an early event during the progression of AD (Masliah et al., 1989; Masliah, 1995). One of critical causes of synapse loss is deficiency in axonal transport (Cull, 1975). Actually, axonal transport is impaired in the brain of $\mathrm{AD}$ patients (Suzuki and Terry, 1967; Younkin et al., 1986; Richard et al., 1989; Praprotnik et al., 1996).

In neurodegenerative diseases including $\mathrm{AD}$, excessive glutamate in extracellular space is recognized as an excitotoxin, playing a role in the development of the diseases (Arias et al., 1998; Lancelot and Beal, 1998). Amyloid $\beta$-protein (A $\beta)$, which accumulates in senile plaques in brains of $\mathrm{AD}$ patients, is also the toxic agent that causes neuronal degeneration and cell death and is profoundly involved in the pathogenesis of AD (Yankner et al.,

Received Feb. 11, 2003; revised Aug. 11, 2003; accepted Aug. 14, 2003.

This work was supported in part by a Grant-in-Aid for Scientific Research (11670638) from the Ministry of Education, Science, Sports and Culture, Japan, to H.H.

Correspondence should be addressed to Dr. Hiromi Hiruma, Department of Physiology, Kitasato University School of Medicine, 1-15-1 Kitasato, Sagamihara 228-8555, Japan. E-mail: hiruma@med.kitasato-u.ac.jp.

Copyright $\odot 2003$ Society for Neuroscience $\quad$ 0270-6474/03/238967-11\$15.00/0
1990; Mattson et al., 1992; Kowall, 1994); however, the influence of these agents on axonal transport has rarely been studied. Here, we investigated the effects of glutamate and $A \beta_{25-35}$, an active fragment of $A \beta$, on fast axonal transport of membrane-bound particles in cultured rat hippocampal neurons using videoenhanced microscopy. Our data suggest that glutamate and $\mathrm{A} \beta_{25-35}$ rapidly inhibit fast axonal transport. The effect of glutamate is mediated by activation of NMDA and AMPA receptors and subsequent $\mathrm{Ca}^{2+}$ influx, whereas the effect of $\mathrm{A} \beta_{25-35}$ occurs via polymerization and aggregation of intracellular actin. Furthermore, we indicate that specific residues and structures are required for the naturally occurring $A \beta$ to inhibit axonal transport.

\section{Materials and Methods}

Cell culture. The experimental protocol was approved by the Animal Experimentation and Ethics Committee of Kitasato University School of Medicine. Hippocampi were removed from fetal Wistar rats on day 16 of gestation, and were immediately immersed in $4^{\circ} \mathrm{C}$ Leibovitz's L- 15 medium (Invitrogen, Carlsbad, CA) containing $0.5 \mathrm{~mm}$ L-glutamine (Wako, Osaka, Japan). These hippocampal tissues were dissected and then incubated for $15 \mathrm{~min}$ at $37^{\circ} \mathrm{C}$ in $\mathrm{Ca}^{2+}, \mathrm{Mg}^{2+}$-free PBS (Invitrogen) containing $0.2 \mathrm{mg} / \mathrm{ml}$ DL-cysteine hydrochloride (Sigma, St. Louis, MO), 0.2 $\mathrm{mg} / \mathrm{ml}$ albumin bovine serum (Sigma), $5 \mathrm{mg} / \mathrm{ml} \mathrm{D}-(+)$-glucose (Wako), $0.55 \mathrm{mg} / \mathrm{ml}$ papain (Worthington Biochemicals, Freehold, NJ), and $0.01 \%$ DNase (Sigma). Then fetal calf serum was added (30\% v/v of PBS) 
to inhibit enzyme activity. Cells were isolated from the tissues using fire-polished pipettes (0.2-0.5 $\mathrm{mm}$ inner diameter). Subsequently, the isolated cells were plated onto polylysinecoated glass coverslips $(30 \times 40 \mathrm{~mm}, 50 \mu \mathrm{m}$ thickness) and cultured for $7 \mathrm{~d}$ in serum-free Neurobasal medium (Invitrogen) containing $0.5 \mathrm{~mm}$ L-glutamine (Invitrogen) and $0.04 \%$ B-27 supplement (Wako) at $37^{\circ} \mathrm{C}$ in a humidified $5 \% \mathrm{CO}_{2}$ atmosphere.

Experimental preparations. The coverslip on which cells were cultured was attached with waterproof tape to the underside of a $0.5-\mathrm{mm}$ thick stainless-steel chamber $(50 \times 80 \mathrm{~mm})$ with a lozenge-shaped hole $(25 \times 35 \mathrm{~mm})$. The volume of the chamber was $\sim 0.45 \mathrm{ml}$. The topside of the chamber was covered with another coverslip, leaving small openings on both sides to perfuse cells with a solution. The culture medium was then replaced with HEPES-buffered salt solution (see below; $37^{\circ} \mathrm{C}$ ). The chamber was mounted onto the stage of an inverted Zeiss Axiomat microscope equipped with an oilimmersed Plan-Apochromat $63 \times$ objective (Carl Zeiss, Oberkochen, Germany). The stage was maintained at $37^{\circ} \mathrm{C}$ by a thermocontroller. The drug-containing solution $(3 \mathrm{ml})$ was injected into one side opening using a Pasteur pipette, and the solution spilling from the other side opening was removed by an infusion pump.

Solutions and drugs. The composition of HEPES-buffered salt solution, $\mathrm{pH}$ 7.4, was (in $\mathrm{mm}): 120 \mathrm{NaCl}, 5 \mathrm{KCl}, 1 \mathrm{CaCl}_{2}, 1 \mathrm{MgCl}_{2}, 10$ HEPES, and $25 \mathrm{D}-(+)$-glucose (all from Wako). $\mathrm{Ca}^{2+}$-free solution consisted of (in $\mathrm{mM}$ ): 120 $\mathrm{NaCl}, 5 \mathrm{KCl}, 1 \mathrm{MgCl}_{2}, 10$ HEPES, $25 \mathrm{D}-(+)-$ glucose, and 2 EGTA (Wako). Amyloid $\beta$-protein fragments $25-35$ ( $\mathrm{A} \beta_{25-35}$; Sigma $)$ and $31-35\left(\mathrm{~A} \beta_{31-35}\right.$; Sigma $)$ were dissolved in distilled water to a concentration of 2 or $10 \mathrm{~mm}$. Fragments 1-40 (A $\beta_{1-40}$; Sigma $)$ and 1-42 (A $\beta_{1-42} ;$ Sigma), and acetyl fragment $15-20$ amide ( $\mathrm{A} \beta_{15-20}$ amide; Sigma) were initially dissolved in $10 \mathrm{~mm} \mathrm{NaOH}$, because they are less soluble in water, and then diluted with distilled water to a concentration of $0.5 \mathrm{~mm}$ for $\mathrm{A} \beta_{1-40}$ and $\mathrm{A} \beta_{1-42}$ and $1 \mathrm{~mm}$ for $\mathrm{A} \beta_{15-20}$ amide. Simultaneously, the $\mathrm{pH}$ of these solutions was adjusted to 7.4 using either $\mathrm{NaOH}$ or $\mathrm{HCl}$. Then these solutions were further diluted at concentrations indicated in Results with HEPESbuffered salt solution and used for experiments on axonal transport and rhodamine-phalloidin stainings. The solutions $(0.5 \mathrm{~mm})$ of $\mathrm{A} \beta_{1-40}$ and $\mathrm{A} \beta_{1-42}$ incubated for $7 \mathrm{~d}$ at room temperature were also used after dilution with HEPES-buffered salt solution. The solutions of $1 \mathrm{~mm} \mathrm{~A} \beta_{15-20}$ amide, $2 \mathrm{~mm} \mathrm{~A} \beta_{31-35}, 2 \mathrm{~mm} \mathrm{~A} \beta_{25-35}, 0.5 \mathrm{~mm} \mathrm{~A} \beta_{1-40}$, and $0.5 \mathrm{~mm} \mathrm{~A} \beta_{1-42}$ were subjected to SDS-PAGE. L-glutamic acid hydrochloride (glutamate; Wako), NMDA (Sigma), AMPA (Sigma), and ( \pm )-MK-801 (Sigma) were dissolved directly in HEPES-buffered salt solution. CNQX (Sigma) and latrunculin B (Biomol, Plymouth Meeting, PA) were each dissolved in dimethyl sulfoxide (DMSO; Wako), and jasplakinolide (Molecular Probes, Eugene, OR) was dissolved in methanol. These organic solutions were then diluted with HEPES-buffered solution. The concentration of DMSO and methanol was $0.01 \%$, and at this concentration these organic solvents had no effect on axonal transport.

Video-enhanced microscopy system. Nomarski images acquired by an inverted microscope were transformed into video images by a video camera (Harpicon, Hamamatsu Photonics, Hamamatsu, Japan) and a cam-

C
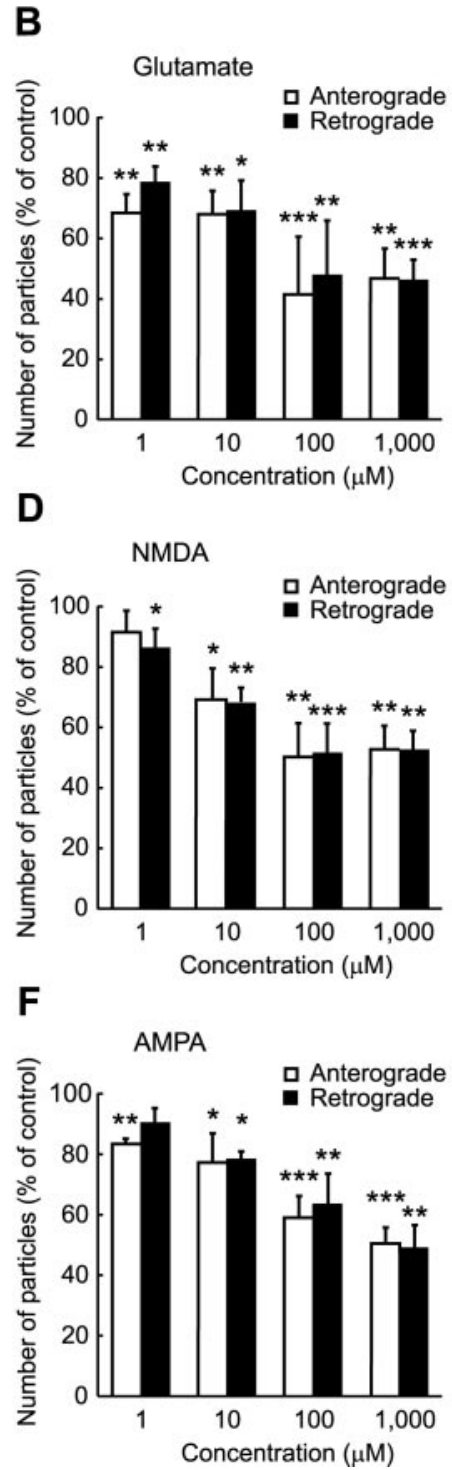

- Anterograde

- Retrograde

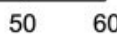

Time (min)

- Anterograde 60

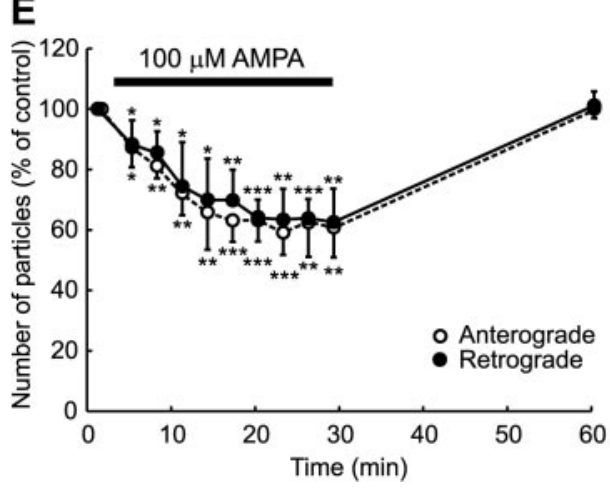

Figure 1. Effects of glutamate and its agonists on the number of particles transported in neurites of cultured rat hippocampal min application of $100 \mu \mathrm{M}$ glutamate $(A), 100 \mu \mathrm{M} \operatorname{NMDA}(C)$, and $100 \mu \mathrm{M} \operatorname{AMPA}(E)$. Note that the number of transported particles was rapidly reduced by these drugs and restored by removal of the drugs. $B, D, F$, Concentration dependence of reduction each application of the drugs is expressed as a percentage of control (the value before application). Data in all panels are expressed as mean \pm SD of five neurons. Error bars represent SD. ${ }^{*} p<0.05 ;{ }^{* *} p<0.005 ;{ }^{* * *} p<0.0005$ compared with control (100\%).

era controller (C2741, Hamamatsu Photonics). The video images were digitalized and enhanced by a video image enhancement system (DVS20, Hamamatsu Photonics), displayed in real-time on a video monitor (C1864, Hamamatsu Photonics), and stored on a video recorder (PVW2800, Sony, Tokyo, Japan). This processing provided a 10,000-fold final magnification on the video monitor.

Analysis of axonal transport. Axonal transport was analyzed from the video replay. The numbers of particles (diameter $\geq 50 \mathrm{~nm}$ ) moving toward the axon terminal (anterograde) and back to the cell body (retrograde) were counted before, during, and after application of the drug. In the control extracellular medium (HEPES-buffered salt solution, $\mathrm{pH} 7.4$, $37^{\circ} \mathrm{C}$ ), the mean numbers of particles (per minute) transported in anterograde and retrograde directions were $59.7 \pm 19.7$ (mean \pm SD; $n=$ $105)$ and $57.5 \pm 19.7(n=105)$, respectively. Averaged data in each experiment are expressed as mean $( \pm S D)$ percentage of the control value that was obtained before the drug application. ANOVA was used to evaluate the statistical significance of fluctuations over time. Differences 
A

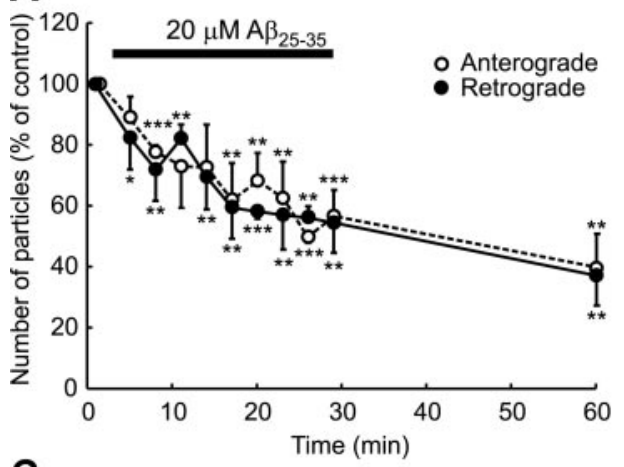

C

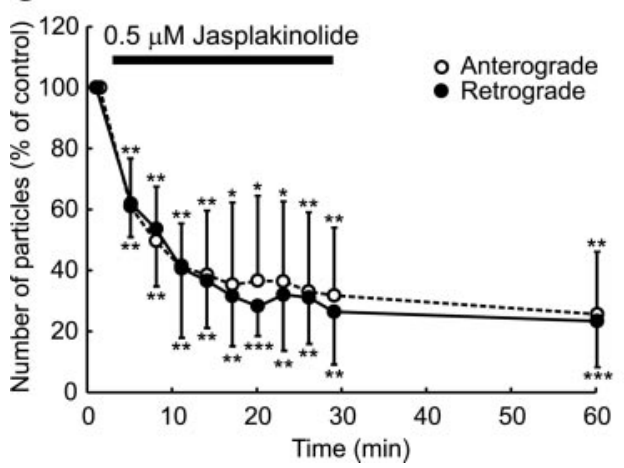

Figure 2. Effects of $A \beta_{25-35}$ and jasplakinolide, an actin-polymerizing agent, on the number of particles transported in neurites of cultured rat hippocampal neurons. $A, C$, Percentage changes in the number of transported particles of control (the value before application) induced by $26 \mathrm{~min}$ application of $20 \mu \mathrm{MA} \beta_{25-35}(A)$ and $0.5 \mu \mathrm{m}$ jasplakinolide ( $C$. Note that the number of transported particles was rapidly and progressively reduced by both drugs and not restored after removal of the drugs. $B$, Concentration dependence of reduction in the number of transported particles induced by $A \beta_{25-35}$. The value obtained at $20 \mathrm{~min}$ after each application of various concentrations of $A \beta_{25-35}$ is expressed as a percentage of control (the value before application). Data in all panels are expressed as mean \pm SD of five neurons. Error bars represent SD. ${ }^{*} p<0.05 ;{ }^{* *} p<0.005 ;{ }^{* * *} p<0.0005$ compared with control (100\%).
B

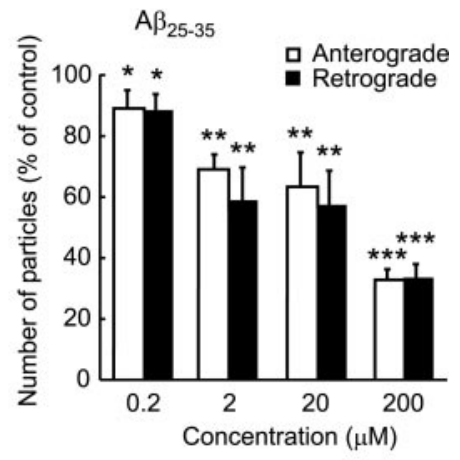

of glutamate. A higher concentration $(1000 \mu \mathrm{M})$ of glutamate produced similar effects. The number of particles transported in both directions was decreased to $40-50 \%$ of control by $1000 \mu \mathrm{M}$ glutamate (Fig. $1 B$ ) and was restored to $\sim 85 \%$ of control 30 min after removal of the drug (data not shown; $n=5$ ). The effects of glutamate were concentration dependent from 1 to $1000 \mu \mathrm{M}$ (Fig. $1 B$ ). Application of NMDA at a concentration of $100 \mu \mathrm{M}$ reduced the number of particles ( $\sim 50 \%$ of control) transported in anterograde and retrograde directions in a similar manner to $100 \mu \mathrm{M}$ glutamate (Fig. $1 C, D$ ). AMPA at a concentration of $100 \mu \mathrm{M}$ also rapidly decreased the number of particles to $\sim 60 \%$ of control in both directions (Fig. $1 E, F$ ). The inhibitory effects induced by each 100 $\mu \mathrm{M}$ NMDA and $100 \mu \mathrm{M}$ AMPA were reversed to control levels $30 \mathrm{~min}$ after washout of the drugs (Fig. 1C,E). The effects of NMDA and AMPA were concentration dependent from 1 to $1000 \mu \mathrm{M}$ (Fig. $1 D, F$ ). Because both NMDA and AMPA mimicked the effects of glutamate, these types of receptors could possibly mediate the effect of glutamate on axonal transport. Video-enhanced microscopy also revealed the progressive formation of membrane blebs in neurites during 26 min application of glutamate at concentrations $\geq 100$ $\mu \mathrm{M}$ (see Fig. $3 A$ ). The size of each bleb was decreased considerably after washout for $30 \mathrm{~min}$.

between control and test conditions were examined for statistical significance using the Student's paired $t$ test.

Rhodamine-phalloidin staining. Hippocampal cells grown on coverslips were treated for 30 min with drugs (glutamate, $A \beta$ fragments, latrunculin $\mathrm{B}$, and a combination of $\mathrm{A} \beta_{25-35}$ and latrunculin $\mathrm{B}$ ) dissolved in a HEPES-buffered solution. Then, cells were fixed with $4 \%$ paraformaldehyde for $3 \mathrm{~min}$ at room temperature. After fixation, they were washed three times with 0.025 м PBS containing $0.3 \%$ Triton X-100 (PBST). The cells were incubated for $30 \mathrm{~min}$ at room temperature in 5 $\mathrm{U} / \mathrm{ml}$ rhodamine-phalloidin (Molecular Probes) dissolved in PBST and washed three times with PBS. The stained cells were examined with a Zeiss Axiovert $135 \mathrm{TV}$ microscope equipped with a $546 \mathrm{~nm}$ excitation filter and a $590 \mathrm{~nm}$ emission filter.

SDS-PAGE. Ten micrograms of each $\mathrm{A} \beta$ in a solution was mixed with Tris-HCl SDS sample buffer, loaded onto 5-20\% gradient acrylamide gel (ATTO, Tokyo, Japan), and electrophoresed. Proteins were visualized with SimplyBlue SafeStain (Invitrogen).

\section{Results}

\section{Effects of glutamate on axonal transport}

Video-enhanced microscopy displayed movement of particles in neurites of cultured rat hippocampal neurons. Continuous application $(26 \mathrm{~min}$ ) of $100 \mu \mathrm{M}$ glutamate significantly reduced the number of particles moving in anterograde and retrograde directions (Fig. $1 A$ ). The number began to decrease within $2 \mathrm{~min}$ and reached a plateau at $40-50 \%$ of the number before the application (control) $20 \mathrm{~min}$ after the start of application. The decreased number was reversed to the control level after a $30 \mathrm{~min}$ washout

\section{Effects of $A \boldsymbol{\beta}_{25-35}$ on axonal transport}

Application of $\mathrm{A} \beta_{25-35}$ at a concentration of $20 \mu \mathrm{M}$ resulted in a rapid and progressive decrease in the number of particles transported in anterograde and retrograde directions during $26 \mathrm{~min}$ application (Fig. $2 A$ ). The effect of $\mathrm{A} \beta_{25-35}$ was concentration dependent from 0.2 to $200 \mu \mathrm{M}$ (Fig. $2 B$ ). Even after washout, the decreasing effect of $20 \mu \mathrm{M} \mathrm{A} \beta_{25-35}$ was progressive and irreversible (Fig. $2 A$ ), although the effect induced by a lower concentration, $2 \mu \mathrm{M}$, of $\mathrm{A} \beta_{25-35}$ applied for $26 \mathrm{~min}$ was restored to the control level within 30 min after washout (data not shown; $n=$ 5 ). We also found that neurites were shrunken by exposure to 20 $\mu \mathrm{M} \mathrm{A} \beta_{25-35}$, and longitudinal microtubules in neurites became clearly visible (Fig. $3 B$ ). This phenomenon was irreversible even after washout. These morphological features were extremely different from those observed in glutamate-treated neurons (Fig. $3 A)$.

Effects of glutamate and $A \boldsymbol{\beta}_{25-35}$ under various conditions It has been reported that $\mathrm{A} \beta$ acts on glutamate receptors (Calligaro et al., 1993; Cowburn et al., 1994, 1997; Le et al., 1995) and that both glutamate and $\mathrm{A} \beta$ exert their toxic effects by $\mathrm{Ca}^{2+}$ influx (Joseph and Han, 1992; Mattson et al., 1992; Hartley et al., 1993; Weiss et al., 1994; Le et al., 1995; Limbrick et al., 2001). A $\beta$ disrupts the intracellular actin network (Davis et al., 1999), and actin depolymerization prevents neurotoxicity of glutamate and $\mathrm{A} \beta_{25-35}$ (Furukawa and Mattson, 1995; Furukawa et al., 1995). 
Actin can interact with microtubules, which are the main tracks for fast axonal transport (Nagele et al., 1988; Bearer and Reese, 1999). The above experiments indicated that glutamate and $\mathrm{A} \beta_{25-35}$ induced morphological changes in neurites, implicating the possible involvement of the cytoskeleton. Therefore, to identify the mechanisms mediating the effects of glutamate and $\mathrm{A} \beta_{25-35}$, we investigated the effects of these two agents in the presence of glutamate receptor antagonists or the actin filament depolymerizer, or in the absence of extracellular $\mathrm{Ca}^{2+}$.

As shown in Figure $4 A$, the inhibitory effect of $100 \mu \mathrm{M}$ glutamate was completely blocked by pretreatment with both the NMDA receptor antagonist MK-801 (20 $\mu \mathrm{M})$ and the AMPA receptor antagonist CNQX $(100 \mu \mathrm{M})$, confirming the involvement of NMDA and AMPA receptors in the effect of glutamate on axonal transport. In contrast, the effect of $20 \mu \mathrm{M}$ $\mathrm{A} \beta_{25-35}$ was not blocked by pretreatment with a combination of $20 \mu \mathrm{M} \mathrm{MK}-801$ and $100 \mu \mathrm{M}$ CNQX (Fig. 4B). In $\mathrm{Ca}^{2+}$-free extracellular medium (with $2 \mathrm{~mm}$ EGTA), the inhibitory effect of $100 \mu \mathrm{M}$ glutamate was abolished completely (Fig. 4C). Similarly, the effects of NMDA $(100 \mu \mathrm{M})$ and AMPA $(100 \mu \mathrm{M})$ were each blocked in the absence of extracellular $\mathrm{Ca}^{2+}$ (data not shown; $n=5$ each). On the contrary, the effect of $20 \mu \mathrm{M} \mathrm{A} \beta_{25-35}$ remained in the absence of extracellular $\mathrm{Ca}^{2+}$ (Fig. 4D). Nevertheless, the effect of $20 \mu \mathrm{M} \mathrm{A} \beta_{25-35}$ was abolished by pretreatment with $5 \mu \mathrm{M}$ latrunculin $\mathrm{B}$, an actin filament depolymerizer (Fig. $4 F$ ). The presence of latrunculin B (5 $\mu \mathrm{M}$ ) did not block the decreasing effect of glutamate (Fig. $4 E$ ), although the decreased axonal transport tended to recover at the end of the glutamate application period (Fig. $4 E$ ). The actinpolymerizing agent jasplakinolide $(0.5 \mu \mathrm{M})$ mimicked the effect of $20 \mu \mathrm{M} \mathrm{A} \beta_{25-35}$ (Fig. $2 C$ ). From these results, the inhibitory effect of glutamate on axonal transport is mediated mainly by $\mathrm{Ca}^{2+}$ influx after activation of NMDA and AMPA receptors. In contrast, the inhibitory effect of $A \beta_{25-35}$ is likely caused by actin polymerization but not by glutamate receptor activation or $\mathrm{Ca}^{2+}$ influx. In these experiments, application of $20 \mu \mathrm{M} \mathrm{MK}-801$ plus $100 \mu \mathrm{M}$ CNQX (Fig. 4A,B) and of $5 \mu \mathrm{M}$ latrunculin B (Fig. 4E, F) did not significantly affect axonal transport, although in 2 of 10 neurons treated with latrunculin B, axonal transport in both anterograde and retrograde directions increased to $>10 \%$ above the control value. In such latrunculin B-sensitive neurons, polymerized or aggregated actin originally present might be depolymerized and dissolved by latrunculin B, allowing axonal transport to increase slightly. We also confirmed that axonal transport was not changed by $\mathrm{Ca}^{2+}$-free solution over a $2 \mathrm{hr}$ experimental period.

\section{Rhodamine-phalloidin staining of the actin cytoskeleton} Cultured hippocampal neurons were stained with rhodaminephalloidin, which specifically binds to filamentous actin, after treatment for $30 \mathrm{~min}$ with glutamate $(100 \mu \mathrm{M}), \mathrm{A} \beta_{25-35}(20 \mu \mathrm{M})$, latrunculin $\mathrm{B}(5 \mu \mathrm{M})$, and a combination of $\mathrm{A} \beta_{25-35}(20 \mu \mathrm{M})$ and latrunculin B $(5 \mu \mathrm{M})$, all dissolved in HEPES-buffered salt solution. The effects of washout (for $30 \mathrm{~min}$ ) after exposure to $\mathrm{A} \beta_{25-35}(20 \mu \mathrm{M})$ were also examined. Control neurons (treated with HEPES-buffered solution alone) revealed a reticular distribution of actin filaments in cell bodies and neurites (Fig. 5A). In glutamate-treated neurons, the distribution of actin filaments was diffuse and the staining was more intense, in particular in the periphery of the cell body, than in control neurons (Fig. 5B), indicating an increase in fragmented actin filaments. Neurons treated with $\mathrm{A} \beta_{25-35}$ showed characteristic features of actin cytoskeleton (Fig. 5C). These neurons were stained intensely, with brightly stained aggregates of actin filaments in both cell bodies and neurites, indicating hyperpolymerization of actin filaments. Interestingly, formation of filopodia, which results from polymerization of actin filaments (Yamada et al., 1970, 1971; Oldenbourg et al., 2000), was observed frequently in $\mathrm{A} \beta_{25-35}$-treated neurons. The same features were observed in neurons that were washed for 30 min after treatment with $A \beta_{25-35}$ (Fig. 5D). In contrast, staining in latrunculin B-treated neurons was weak and diffuse in both cell bodies and neurites (Fig. 5E), indicating dissolution of actin filaments. Simultaneous treatment with latrunculin $\mathrm{B}$ and $\mathrm{A} \beta_{25-35}$ abolished the characteristic features observed in neurons treated with $\mathrm{A} \beta_{25-35}$ alone (Fig. $5 F$ ).

\section{Effects of various $A \beta$ fragments}

$\mathrm{A} \beta$ molecules found mainly in senile plaques are $\mathrm{A} \beta_{1-40}$ and $\mathrm{A} \beta_{1-42}$ (Iwatsubo et al., 1994). Recent studies have shown that $\mathrm{A} \beta_{1-40}$ and $\mathrm{A} \beta_{1-42}$ assemblies, soluble oligomers and fibril 
A
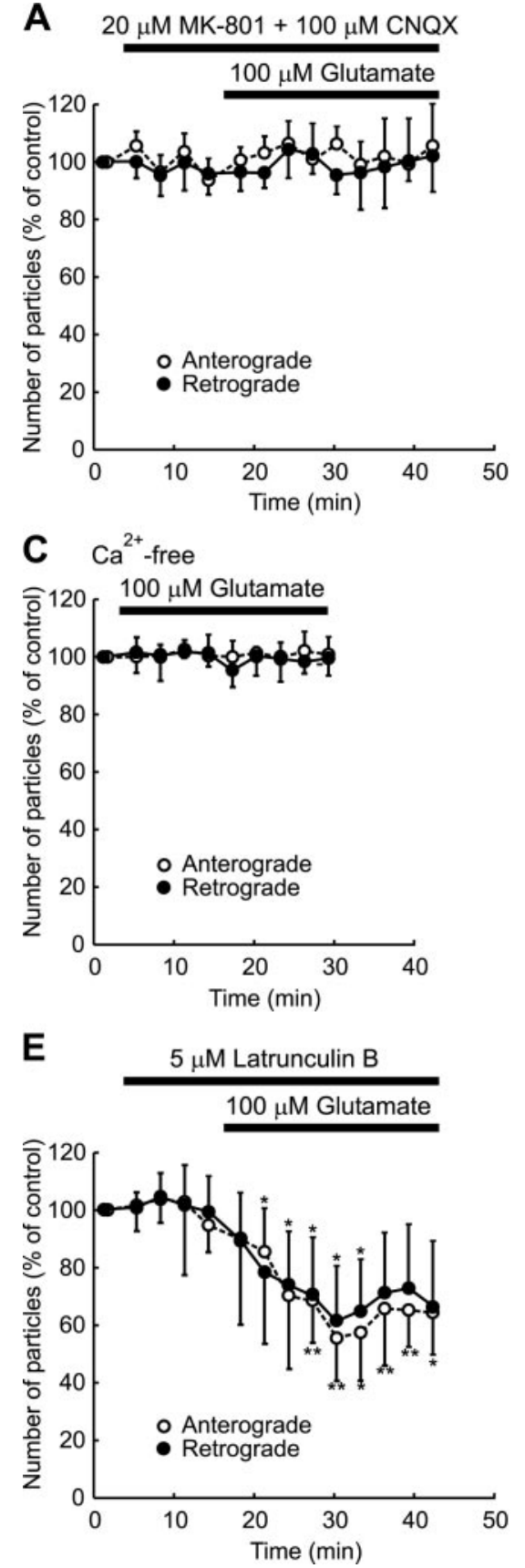

B
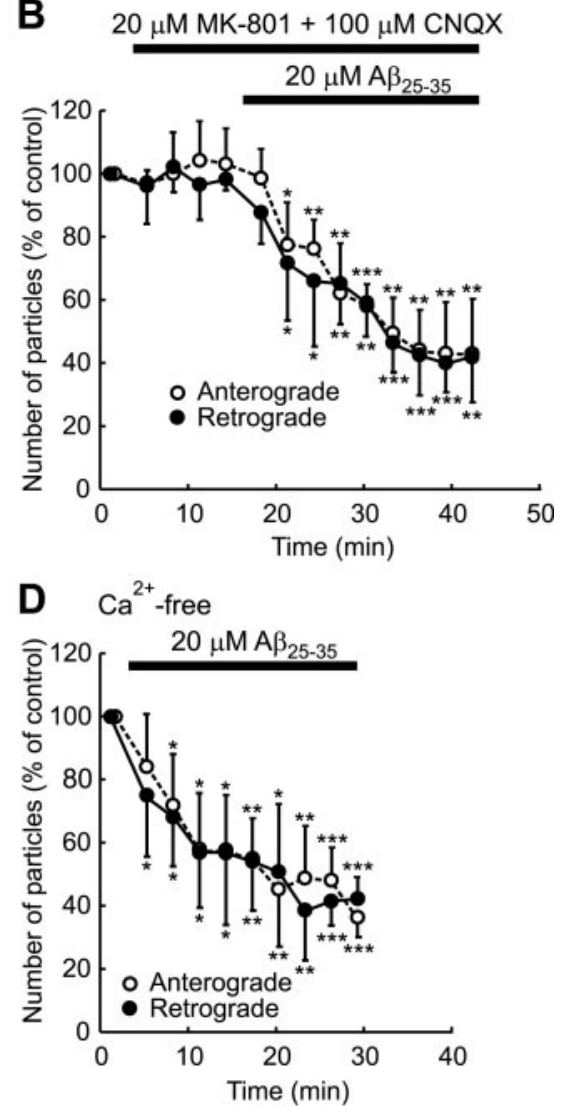

$\mathbf{F}$

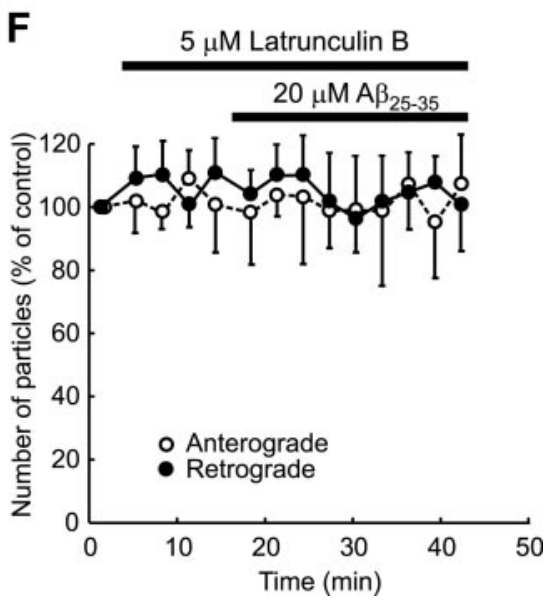

Figure 4. Effects of glutamate and $A \beta_{25-35}$ under various conditions. Data represent percentage changes in the number of transported particles of control (the value before application). Glutamate $(100 \mu \mathrm{M})(A, C, E)$ and $A \beta_{25-35}(20 \mu \mathrm{M})(B, D, F)$ were applied after treatment with a combination of $20 \mu \mathrm{M}$ MK-801, an NMDA receptor antagonist, and $100 \mu \mathrm{M}$ CNQX, an AMPA receptor antagonist $(A, B)$, in $\mathrm{Ca}^{2+}$-free solution $(C, D)$, and after treatment with $5 \mu$ m latrunculin $B$, an actin depolymerizer $(E, F)$. Each data point indicates the mean $\pm S D$ of the values obtained from five neurons. Error bars represent $S D .{ }^{*} p<0.05 ;{ }^{* *} p<$ $0.005 ;{ }^{* * *} p<0.0005$ compared with control (100\%).

intermediates (protofibrils), have potent neurotoxic activities (Lambert et al., 1998; Hartley et al., 1999; Walsh et al., 1999). Because $A \beta$ is secreted from brain cells as a monomeric form (Haass et al., 1992), the process toward the assembly is necessary for neurotoxicity of $\mathrm{A} \beta_{1-40}$ and $\mathrm{A} \beta_{1-42}$. Hydrophobic residues of $\mathrm{A} \beta$ are correlated with fibril formation (Li et al., 1999; Petkova et al., 2002). Thus, we further examined the effects of the hydrophobic $A \beta$ fragments, $A \beta_{15-20}$ amide and $A \beta_{31-35}$, and full-length $\mathrm{A} \beta_{1-40}$ and $\mathrm{A} \beta_{1-42}$, to identify residues and structures contributing to the inhibition of axonal transport. $A \beta$ fragments were used immediately after dissolution (fresh condition). Because $\mathrm{A} \beta_{1-40}$ and $\mathrm{A} \beta_{1-42}$ assemble to form large structures during incubation (Pike et al., 1991; Kayed et al., 2003), the effects of these agents incubated for $7 \mathrm{~d}$ were also investigated. Light microscopic screening and SDS-PAGE were performed simultaneously to examine the solubility and assembly state of $A \beta$ fragments in solution (Fig. $6 A-E$ ). The results are summarized in Table $1 . \mathrm{A} \beta_{31-35}(20 \mu \mathrm{M})$ but not $\mathrm{A} \beta_{15-20}$ amide $(20 \mu \mathrm{M})$ induced intracellular actin aggregation and inhibition of axonal transport similar to that of $\mathrm{A} \beta_{25-35}$. Thus, the active site in $\mathrm{A} \beta$ is probably present in residues $31-35$. Among fresh and incubated full-length $A \beta s$, only incubated $\mathrm{A} \beta_{1-42}(20 \mu \mathrm{M})$ was effective. In contrast, fresh $A \beta_{1-40}(20 \mu \mathrm{M})$, incubated $\mathrm{A} \beta_{1-40}(20 \mu \mathrm{M})$, or fresh $\mathrm{A} \beta_{1-42}(20 \mu \mathrm{M})$ had no effect. SDS-PAGE analysis revealed that $\mathrm{A} \beta_{15-20}$ amide and $\mathrm{A} \beta_{31-35}$ were present in low molecular weight forms $(<1 \mathrm{kDa})$ (Fig. 6C). A $\beta_{25-35}$ was composed of both low molecular weight molecules $(\sim 1 \mathrm{kDa})$ and aggregates that did not enter the SDS-PAGE gel (Fig. 6C), and this fragment formed precipitates detected by light microscopy (Fig. 6A); that is, in these shorter fragments, there was no correlation between their structures and activities. Fresh $\mathrm{A} \beta_{1-40}$ was primarily monomeric (Fig. 6D), whereas incubated $\mathrm{A} \beta_{1-40}$ additionally produced aggregates (Fig. 6E) and precipitates (Fig. 6B). Fresh $\mathrm{A} \beta_{1-42}$ contained monomers, pentamers, and hexamers (Fig. 6D), whereas incubated $\mathrm{A} \beta_{1-42}$ contained $30-100 \mathrm{kDa}$ high molecular weight forms in addition to the lower molecular forms observed in fresh $\mathrm{A} \beta_{1-42}$ (Fig. $6 E$ ). Thus, among various states of full-length $\mathrm{A} \beta$ observed in this experiment, only high molecular weight assemblies $(30-100 \mathrm{kDa})$ of $\mathrm{A} \beta_{1-42}$ appear to participate in the inhibition of axonal transport, whereas lower molecular weight molecules (monomers, pentamers, and hexamers) of $\mathrm{A} \beta_{1-40} / \mathrm{A} \beta_{1-42}$ or aggregates and precipitates of $\mathrm{A} \beta_{1-40}$ do not.

\section{Discussion}

Inhibitory effects of glutamate and $\mathrm{A} \beta$ on axonal transport

We show evidence that glutamate and $\mathrm{A} \beta_{25-35}$ inhibit anterograde and retrograde fast axonal transport in cultured rat hippocampal neurons. Only a few previous reports have described the effects of these agents on axonal transport. One of them has shown that glutamate inhibits axonal transport of neurofilaments (Ackerley et al., 2000). Neurofilaments, carried within axons by slow axonal transport, have recently been found to be transported by similar mechanisms to fast axonal transport, microtubule-based and kinesin and dynein motors-dependent 
mechanisms, with a long rest period (Roy et al., 2000; Wang et al., 2000). One more report has demonstrated, using immunohistochemistry, that human $\mathrm{A} \beta_{1-42}$ applied in vivo inhibits fast axonal transport of acetylcholinesterase, amyloid precursor protein, vesicular acetylcholine transporter, and synaptophysin in the sciatic nerve of the rat (Kasa et al., 2000). Therefore, the present and previous studies strongly suggest that both glutamate and $\mathrm{A} \beta$ are agents that inhibit fast axonal transport. We also found that the response of axonal transport to glutamate and $\mathrm{A} \beta_{25-35}$ was rapid, being detected within a few minutes after the start of stimulation. Thus, axonal transport may be one of the early targets for toxicity of these two agents.

The effect of glutamate, even when applied at high concentrations $(\geq 100 \mu \mathrm{M})$ for $26 \mathrm{~min}$, was reversed after removal of glutamate. These exposure concentrations and duration are sufficient to cause cell death in cultured neurons $24 \mathrm{hr}$ later (Hartley et al., 1993). Despite this, the effect of glutamate on axonal transport was reversible, probably by receptor-mediated mechanisms as described below. In contrast, the effect of $\mathrm{A} \beta_{25-35}$ at $20 \mu \mathrm{M}$, a concentration able to kill neuronal cells several days later (Yankner et al., 1990; Weiss et al., 1994), was irreversible and progressive even after washout. Similar prolongation and irreversibility of the effects of $\mathrm{A} \beta$ have been reported previously. $\mathrm{A} \beta$, at various concentrations, induces a prolonged activation of pro-apoptotic markers, caspase 3 and annexin $\mathrm{V}$ binding (A. R. White et al., 2001), an irreversible inward cation current (Furukawa et al., 1994; Sanderson et al., 1997), and a prolonged glutamateinduced $\left[\mathrm{Ca}^{2+}\right]_{\mathrm{i}}$ increase even after removal of glutamate (Scorziello et al., 1996) in neuronal or neuron-like cells. In astrocytes, $A \beta$ irreversibly produces a reactive morphological change (Kato et al., 1997). Thus, A $\beta$ can cause prolonged and irreversible changes in some cellular structures and functions including axonal transport. The present study using rhodamine-phalloidin revealed that $20 \mu \mathrm{M}$ $\mathrm{A} \beta_{25-35}$-induced changes in the actin cytoskeleton were irreversible after removal of $\mathrm{A} \beta_{25-35}$. Therefore, persistent intracellular structural changes induced by $\mathrm{A} \beta_{25-35}$ may result in an irreversible impairment of axonal transport.

\section{Different mechanisms of inhibition of} axonal transport by glutamate and $\mathrm{A} \boldsymbol{\beta}$ Glutamate can trigger $\mathrm{Ca}^{2+}$ influx after activation of NMDA and AMPA receptors to cause excitotoxicity (Frandsen and Schousboe, 1993; Hartley et al., 1993). In agreement with this, we find that the inhibitory effect of glutamate on axonal transport is mediated by activation of
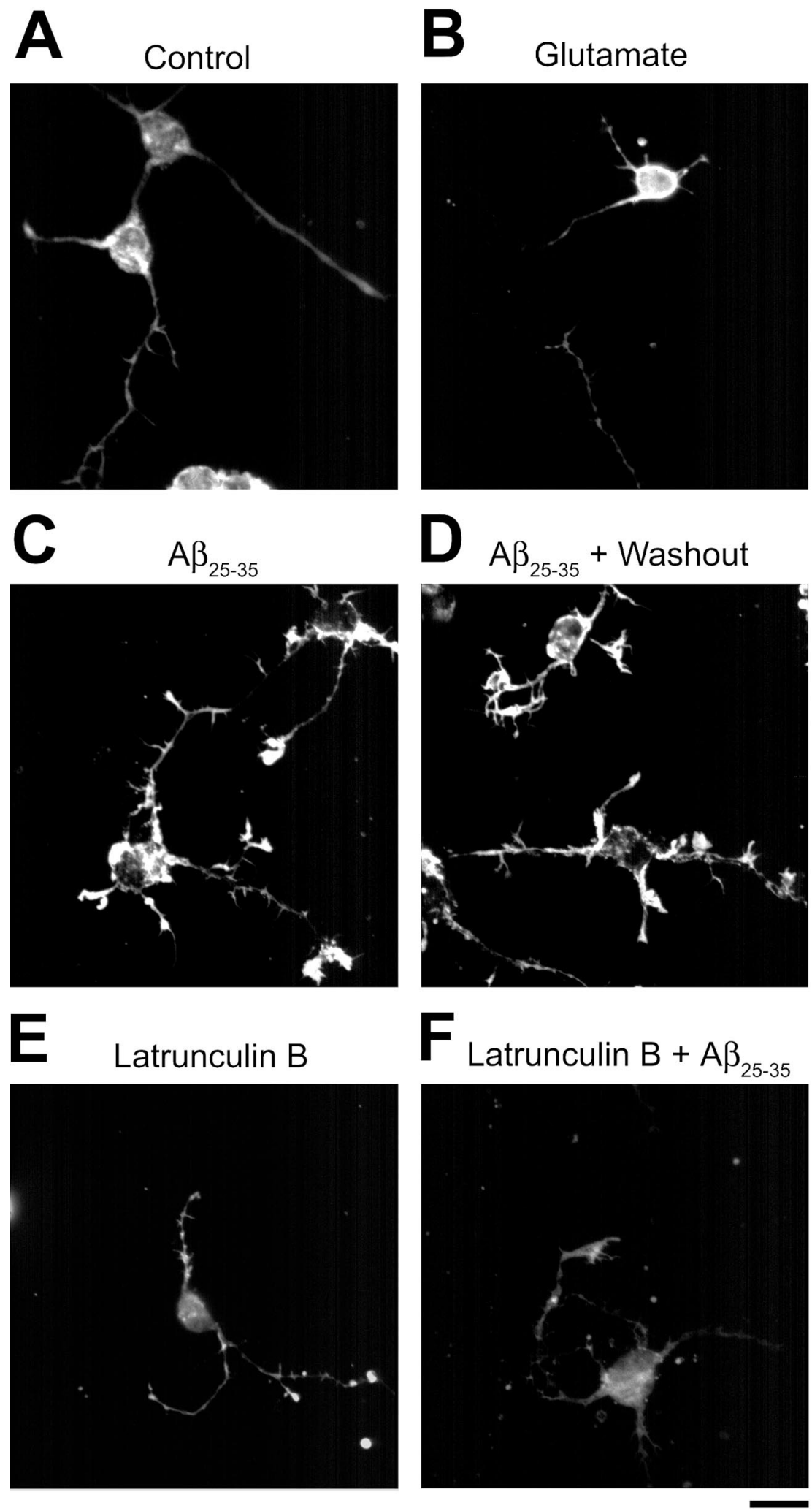

Figure 5. Rhodamine-phalloidin staining of actin filaments in cultured hippocampal neurons. Neurons were stained with rhodamine-phalloidin after treatment of drugs dissolved in HEPES-buffered solution. $A$, Control (treatment with HEPES-buffered solution alone for $30 \mathrm{~min}$ ). $B$, Treatment with $100 \mu \mathrm{m}$ glutamate for $30 \mathrm{~min}$. C, Treatment with $20 \mu \mathrm{m} \mathrm{A} \beta_{25-35}$ for $30 \mathrm{~min}$. D, Treatment with $20 \mu \mathrm{mA} \beta_{25-35}$ for 30 min followed by washout for 30 min. $E$, Treatment with $5 \mu \mathrm{m}$ latrunculin $B$ for 30 min. F, Simultaneous treatment with $20 \mu \mathrm{mA} \beta_{25-35}$ and $5 \mu \mathrm{m}$ latrunculin B for $30 \mathrm{~min}$. Scale bar, $20 \mu \mathrm{m}$. 
A
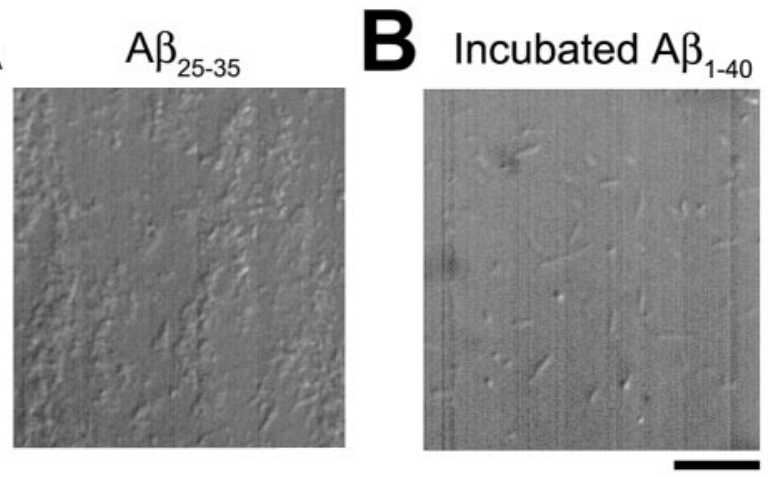

C

$\mathbf{F}$

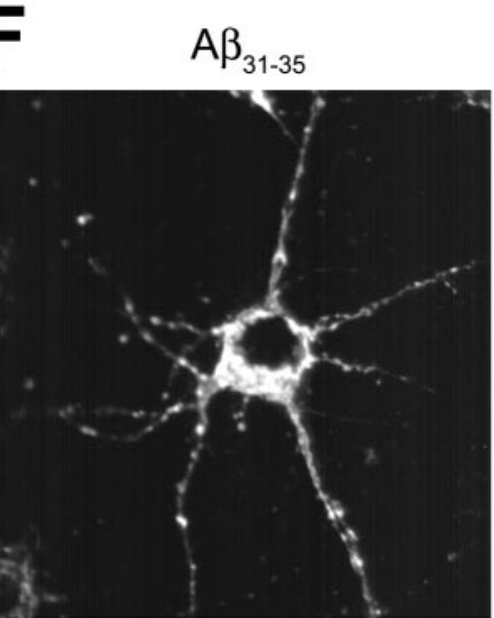

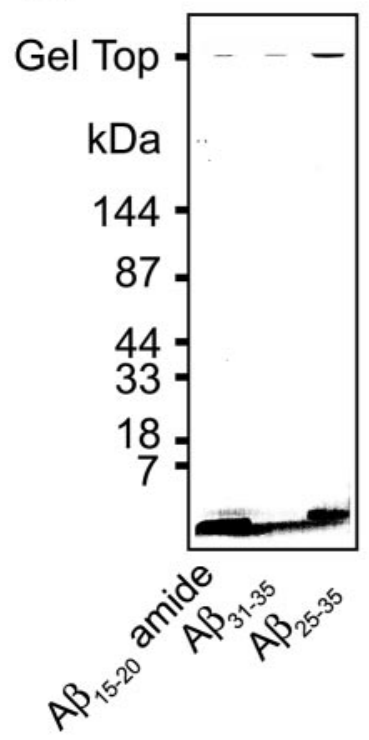
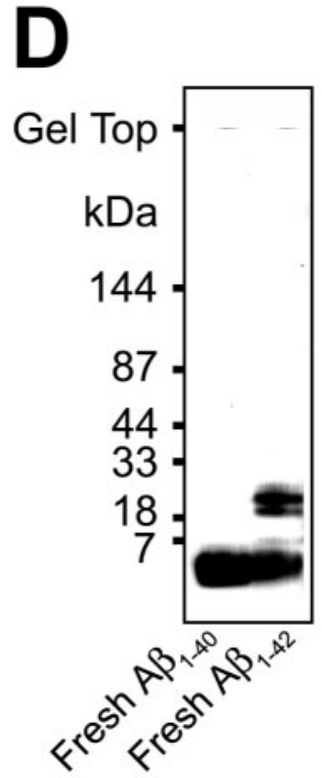
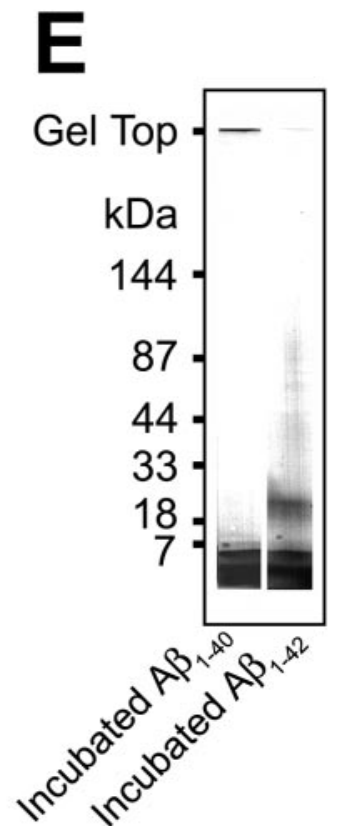
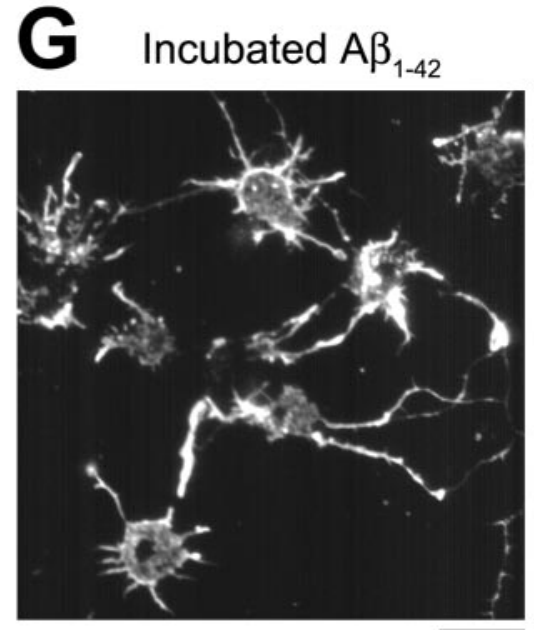

Figure 6. Photographs representing properties of various $A \beta$ fragments. $A, B$, Precipitates detected under light microscopy in $A \beta_{25-35}$ solution $(A)$ and in incubated $A \beta_{1-40}$ solution $(B) . A \beta_{25-35}$ produced cotton-like precipitates $(A)$, and incubated $A \beta_{1-40}$ formed fiber-like or amorphous precipitates $(B)$. Scale bar, $10 \mu \mathrm{m}$. $C-E$, SDS-PAGE profiles of various $A \beta$ fragments. $F, G$, Rhodamine-phalloidin staining of intracellular actin filaments in hippocampal neurons treated with $A \beta_{31-35}$ $(F)$ and with incubated $A \beta_{1-42}(G) . A \beta_{31-35}(20 \mu \mathrm{M})$ and incubated $A \beta_{1-42}(20 \mu \mathrm{M})$ formed intracellular actin aggregates. Scale bar, $20 \mu \mathrm{m}$. both NMDA and AMPA receptors and subsequent $\mathrm{Ca}^{2+}$ influx. In contrast, the effect of $\mathrm{A} \beta_{25-35}$ is unlikely to be mediated by NMDA or AMPA receptors, or by $\mathrm{Ca}^{2+}$ influx. This seems to be inconsistent with the previously reported mechanisms of $\mathrm{A} \beta$-induced neurodegeneration and cell death. It has been proposed that $\mathrm{A} \beta$ has an affinity for the agonist recognition sites of the NMDA receptor (Cowburn et al., 1994; 1997) and increases intracellular $\mathrm{Ca}^{2+}$ through an influx of extracellular $\mathrm{Ca}^{2+}$ in cultured neurons (Joseph and Han, 1992; Weiss et al., 1994). Toxicity of $\mathrm{A} \beta$ can be inhibited by the NMDA receptor antagonist (Le et al., 1995) and by $\mathrm{Ca}^{2+}$ channel blockers (Weiss et al., 1994). On the contrary, our proposed mechanisms are compatible with some other previous investigations. Cell death induced by $\mathrm{A} \beta$ is not mediated by intracellular early $\mathrm{Ca}^{2+}$ accumulation, because $\mathrm{A} \beta$ inhibits spontaneous $\mathrm{Ca}^{2+}$ oscillation and does not affect high $\mathrm{K}^{+}$- and glutamate-evoked $\mathrm{Ca}^{2+}$ increase (Gao et al., 1998). The neurotoxic effect of $\mathrm{A} \beta$ is not blocked by glutamate receptor antagonists (Busciglio et al., 1993; Weiss et al., 1994; Gray and Patel, 1995) or by $\mathrm{Ca}^{2+}$ channel blockers (Whitson and Appel, 1995). Collectively considered, $A \beta$ can trigger multiple signaling cascades leading to neuronal cell damage, and one or some of which may be specific for the impairment of axonal transport. Here we found that the inhibitory effect of $\mathrm{A} \beta_{25-35}$ on axonal transport was abolished by the actindepolymerizing agent latrunculin B. In addition, the actin-polymerizing agent jasplakinolide mimicked the effect of $\mathrm{A} \beta_{25-35}$, and $\mathrm{A} \beta_{25-35}$ induced aggregation of intracellular actin. Because aggregation of actin is supposed to result from actin polymerization (Lee et al., 1998; Fabian et al., 1999; Bai et al., 2002), our results suggest that the inhibitory effect of $\mathrm{A} \beta_{25-35}$ on axonal transport occurs via polymerization and subsequent aggregation of actin. Neurite shrinkage and filopodia formation induced by $\mathrm{A} \beta_{25-35}$, revealed by the present morphological investigation, may also be explained as being caused by polymerization of actin filaments. Actin polymerization dynamics involves changes in cell shape and size. Filopodia are formed by polymerization of actin (Yamada et al., 1970, 1971; Oldenbourg et al., 2000). Such filopodia formations may be involved in the previously reported neurotrophic action of $\mathrm{A} \beta$ (Whitson et al., 1990; Yankner et al., 1990; Koo et al., 1993), which appears to contribute to aberrant sprouting of neurites around senile plaques in $\mathrm{AD}$ (Whitson et al., 1990; Koo et al., 1993). Furthermore, in support of our conclusion, $\mathrm{A} \beta$ has been suggested to cause disruption of the intracellular actin network (Davis et al., 1999), which results from actin 
Table 1. Properties and effects of various $A \beta$ fragments

\begin{tabular}{|c|c|c|c|c|}
\hline$A \beta$ fragment & $\begin{array}{l}\text { Precipitates detected } \\
\text { under light microscopy }\end{array}$ & Structural properties analyzed by SDS-PAGE & $\begin{array}{l}\text { Intracellular actin } \\
\text { aggregation }\end{array}$ & $\begin{array}{l}\text { Effects on } \\
\text { axonal transport }\end{array}$ \\
\hline$A \beta_{15-20}$ amide & - & Low molecular weight forms ( $<1 \mathrm{kDa}$ ) & - & No effect \\
\hline$A \beta_{31-35}$ & - & Low molecular weight forms (<1 kDa) & + & Inhibitory \\
\hline$A \beta_{25-35}$ & + & $\begin{array}{l}\text { Low molecular weight forms ( } \sim 1 \mathrm{kDa}) \\
\text { Aggregates }\end{array}$ & + & Inhibitory \\
\hline Fresh $A \beta_{1-40}$ & - & Monomers & - & No effect \\
\hline Incubated $A \beta_{1-40}$ & + & $\begin{array}{l}\text { Monomers } \\
\text { Aggregates }\end{array}$ & - & No effect \\
\hline Fresh $A \beta_{1-42}$ & - & $\begin{array}{l}\text { Monomers } \\
\text { Pentamers } \\
\text { Hexamers }\end{array}$ & - & No effect \\
\hline Incubated $A \beta_{1-42}$ & - & $\begin{array}{l}\text { Monomers } \\
\text { Pentamers } \\
\text { Hexamers } \\
\text { High molecular weight forms }(30-100 \mathrm{kDa})\end{array}$ & + & Inhibitory \\
\hline
\end{tabular}

$\mathrm{A} \beta$ fragments dissolved in HEPES-buffered salt solution, $\mathrm{pH} 7.4$, at a concentration of $20 \mu \mathrm{M}$ were used for light microscopic analysis, intracellular actin observation with rhodamine-phalloidin, and axonal transport study unde video-enhanced microscopy. Ten micrograms of each $A \beta$ fragment dissolved in an aqueous solution were subjected to SDS-PAGE. + , Detected; - , not detected.

polymerization (Senderowicz et al., 1995; Fabian et al., 1999; S. R. White et al., 2001) as well as depolymerization. Hirano bodies, one of pathologic features found frequently in neurites adjacent to a senile plaque in the AD brain, include abundant actin polymers (Goldman, 1983; Galloway et al., 1987). Depolymerization of actin attenuates $\mathrm{A} \beta$ neurotoxicity (Furukawa and Mattson, $1995)$. Thus, actin polymerization appears to relate to some neurotoxic effects of $\mathrm{A} \beta$. Certainly, our results are strongly supported by recent evidence that $A \beta$ induces actin polymerization to form stress fibers in SN1 cells, a septal neuronal cell line, and in cultured mouse hippocampal neurons (Song et al., 2002). Presently, it is not known how extracellular $\mathrm{A} \beta$ polymerizes intracellular actin; however, because $\mathrm{A} \beta$ forms pores on cell membrane ( $\mathrm{Fu}-$ rukawa et al., 1994; Sanderson et al., 1997; Kawahara and Kuroda, 2000) and activates intracellular cascades that cause actin polymerization, such as the $\mathrm{p} 38$ mitogen-activated protein kinase (MAPK) signaling pathway (Song et al., 2002), A $\beta$ could interact with intracellular actin.

Axonal transport can be modified by the dynamics of the cytoskeleton, including actin filaments. A number of observations indicate the participation of actin in fast axonal transport of organelles. Organelles can be transported axonally along actin filaments (Kuznetsov et al., 1992; Morris and Hollenbeck, 1995). Microtubule-based tracks for fast axonal organelle transport include actin filaments (Bearer and Reese, 1999), and actin is a component of granular, microtubule-associated cross-bridges that connect to other structures, including other microtubules, neurofilaments, organelles, and plasma membrane (Nagele et al., 1988). Changes in intracellular actin states have been shown to modify axonal transport (Goldberg et al., 1980; Goldberg, 1982; Brady et al., 1984; Kuznetsov et al., 1992; Morris and Hollenbeck, 1995; Ligon and Steward, 2000). Several early studies suggest that some actin-depolymerizing agents such as cytochalasins, DNase I, and gelsolin seem to inhibit fast axonal transport (Goldberg et al., 1980; Isenberg et al., 1980; Goldberg, 1982; Brady et al., 1984; Nemhauser and Goldberg, 1985; Kuznetsov et al., 1992), which appears to be inconsistent with the present results indicating that polymerization and aggregation of actin inhibit axonal transport; however, some of these agents aggregate actin, on the other hand. Indeed, fast axonal transport of mitochondria is impeded by cytochalasin $\mathrm{D}$-induced actin aggregates but not affected by latrunculin B (Ligon and Steward, 2000). Nemhauser and Goldberg (1985) have described the possibility of the secondary effects of
DNase I on axonal transport, i.e., a substantial part of the inhibition of fast axonal transport caused by DNase I is attributable to depolymerization of microtubules, or DNase I induces a decrease in microtubules by reducing actin filaments. Indeed, polymerization of actin with jasplakinolide inhibits intracellular motility in non-neuronal cells, HL60 cells, and monocytes (Fabian et al., 1999). These previous studies support our proposal that actin polymerization and aggregation induced by $\mathrm{A} \beta$ inhibit fast axonal transport.

\section{$A \beta$ residues and structures contributing to the inhibition of axonal transport}

Furthermore, we investigated various $\mathrm{A} \beta$ fragments including $\mathrm{A} \beta_{1-40}$ and $\mathrm{A} \beta_{1-42}$, the main fragments found in senile plaques in the human $\mathrm{AD}$ brain. We obtained the results that $\mathrm{A} \beta_{31-35}$ induced aggregation of actin filaments and inhibition of axonal transport similarly to $\mathrm{A} \beta_{25-35}$, whereas $\mathrm{A} \beta_{15-20}$ amide had no effects. Thus, the active site in full-length $A \beta$ may reside in fragments 31-35, as suggested previously (Yan et al., 1999; Qi and Qiao, 2001; Bond et al., 2003). In these shorter fragments, there was no correlation between structures and activities. In contrast, in full-length $A \beta$, the activity seems to depend on its structure. Our results indicated that incubated $\mathrm{A} \beta_{1-42}$ produced an inhibition of axonal transport and actin aggregation, whereas fresh $\mathrm{A} \beta_{1-40}$, incubated $\mathrm{A} \beta_{1-40}$, or fresh $\mathrm{A} \beta_{1-42}$ had no effect. Because incubated $\mathrm{A} \beta_{1-42}$ but not fresh $\mathrm{A} \beta_{1-42}$ contained $30-100 \mathrm{kDa}$ molecules corresponding to higher oligomers or protofibrils (or protofilaments), these structures of $\mathrm{A} \beta_{1-42}$ may participate in the impairment of axonal transport. Our data also indicate that $\mathrm{A} \beta_{1-40}$ in monomers, aggregates, or participates has no apparent effect, although the possibility remains that $\mathrm{A} \beta_{1-40}$ in other states is effective. These results are consistent with the current concept that soluble oligomers and protofibrils of full-length $\mathrm{A} \beta$ are neurotoxic (Lambert et al., 1998; Hartley et al., 1999; Walsh et al., 1999; Dahlgren et al., 2002; Kim et al., 2003). Furthermore, on the basis of our results, we postulate that residues 31-35 may be the key to understanding the structure dependence of the activity of full-length $\mathrm{A} \beta$. We propose that $\mathrm{A} \beta$ is effective when it represents a structure in which the active site can access the cell membrane. This proposal is supported by the recent $\mathrm{x}$-ray diffraction study by Bond et al. (2003). They suggest that residues $31-35$ are exposed at the surface of oligomeric $A \beta$ and interact with the cell membrane. Assembly of full-length $A \beta$ can be driven by the for- 
mation of $\beta$-sheet structures where hydrophobic residues $17-20$ are in contact with hydrophobic residues 31-35 (Lee et al., 1995; Li et al., 1999). Monomers of $\mathrm{A} \beta_{1-40}$ and $\mathrm{A} \beta_{1-42}$ exist as random extended chain (Zeng et al., 2001) or $\alpha$-helix (Barrow and Zagorski, 1991; Coles et al., 1998; Zeng et al., 2001), and dimer and small oligomers can form a $\beta$-sheet (Barrow and Zagorski, 1991; Chaney et al., 1998) or an irregular structure that is not $\alpha$-helix or $\beta$-structure (Huang et al., 2000). Higher oligomers form $\beta$-sheet (Huang et al., 2000) and appear to combine with each other to build protofibrils (or protofilaments), and then protofibrils (or protofilaments) associate into larger fibrils (Chaney et al., 1998; Walsh et al., 1999; Serpell, 2000; Petkova et al., 2002; Bitan et al., 2003). Because the results of the present study as well as other recent studies (Lambert et al., 1998; Hartley et al., 1999; Walsh et al., 1999; Dahlgren et al., 2002) indicate that full-length $A \beta$ assemblies, such as higher oligomers and protofibrils, are toxic, the $\beta$-sheet formation seems to contribute to toxicity in full-length $\mathrm{A} \beta$. In much larger assemblies such as fibrils, however, hydrophobic $\beta$-sheets that contain residues $31-35$ are associated laterally, and then the $\beta$-sheet structures are positioned inside the $\mathrm{A} \beta$ assembly or are shielded by hydrophilic residues (Chaney et al., 1998; Petkova et al., 2002). In such states, toxic 31-35 residues can no longer access the cell membrane, and therefore $\mathrm{A} \beta$ may become ineffective; however, further structural evidence is needed to confirm this speculation.

In summary, glutamate and $\mathrm{A} \beta_{25-35}$ rapidly inhibit anterograde and retrograde fast axonal transport in cultured hippocampal neurons. The effects of glutamate are mediated by activation of NMDA and AMPA receptors and subsequent $\mathrm{Ca}^{2+}$ influx, which is different from the inhibitory mechanisms of $\mathrm{A} \beta_{25-35}$. The latter is likely mediated by actin polymerization and aggregation. The ability of $\mathrm{A} \beta$ to exert these effects seems to require specific amino acid residues and structures. These results may provide insight into the early pathogenetic mechanisms of $\mathrm{AD}$.

\section{References}

Ackerley S, Grierson AJ, Brownlees J, Thornhill P, Anderton BH, Leigh PN, Shaw CE, Miller CC (2000) Glutamate slows axonal transport of neurofilaments in transfected neurons. J Cell Biol 150:165-175.

Arias C, Becerra-García F, Tapia R (1998) Glutamic acid and Alzheimer's disease. Neurobiology 6:33-43.

Bai R, Covell DG, Liu C, Ghosh AK, Hamel E (2002) (-)-Doliculide, a new macrocyclic depsipeptide enhancer of actin assembly. J Biol Chem 277:32165-32171.

Barrow CJ, Zagorski MG (1991) Solution structures of $\beta$ peptide and its constituent fragments: relation to amyloid deposition. Science 253:179-182.

Bearer EL, Reese TS (1999) Association of actin filaments with axonal microtubule tracts. J Neurocytol 28:85-98.

Bitan G, Kirkitadze MD, Lomakin A, Vollers SS, Benedek GB, Teplow DB (2003) Amyloid $\beta$-protein (A $\beta$ ) assembly: $A \beta 40$ and $A \beta 42$ oligomerize through distinct pathways. Proc Natl Acad Sci USA 100:330-335.

Bond JP, Deverin SP, Inouye H, El-Agnaf OM, Teeter MM, Kirschner DA (2003) Assemblies of Alzheimer's peptides $A \beta 25-35$ and A $331-35$ : reverse-turn conformation and side-chain interactions revealed by X-ray diffraction. J Struct Biol 141:156-170.

Brady ST, Lasek RJ, Allen RD, Yin HL, Stossel TP (1984) Gelsolin inhibition of fast axonal transport indicates a requirement for actin microfilaments. Nature 310:56-58.

Brimijoin WS (1982) Abnormalities of axonal transport: are they a cause of peripheral nerve disease? Mayo Clin Proc 57:707-714.

Busciglio J, Yeh J, Yankner BA (1993) $\beta$-Amyloid neurotoxicity in human cortical culture is not mediated by excitotoxins. J Neurochem 61:1565-1568.

Calligaro DO, O’Malley PJ, Monn JA (1993) $\beta$-Amyloid (25-35) or sub- stance $\mathrm{P}$ stimulates $\left[{ }^{3} \mathrm{H}\right] \mathrm{MK}-801$ binding to rat cortical membranes in the presence of glutamate and glycine. J Neurochem 60:2297-2303.

Chaney MO, Webster SD, Kuo YM, Roher AE (1998) Molecular modeling of the $A \beta 1-42$ peptide from Alzheimer's disease. Protein Eng 11:761-767.

Coles M, Bicknell W, Watson AA, Fairlie DP, Craik DJ (1998) Solution structure of amyloid $\beta$-peptide $(1-40)$ in a water-micelle environment. Is the membrane-spanning domain where we think it is? Biochemistry 37:11064-11077.

Cowburn RF, Messamore E, Li ML, Winblad B, Sundström E (1994) $\beta$-Amyloid related peptides exert differential effects on $\left[{ }^{3} \mathrm{H}\right] \mathrm{MK}-801$ binding to rat cortical membranes. NeuroReport 5:405-408.

Cowburn RF, Wiehager B, Trief E, Li-Li M, Sundström E (1997) Effects of $\beta$-amyloid-(25-35) peptides on radioligand binding to excitatory amino acid receptors and voltage-dependent calcium channels: evidence for a selective affinity for the glutamate and glycine recognition sites of the NMDA receptor. Neurochem Res 22:1437-1442.

Cull RE (1975) Role of axonal transport in maintaining central synaptic connections. Exp Brain Res 24:97-101.

Dahlgren KN, Manelli AM, Stine WB Jr, Baker LK, Krafft GA, LaDu MJ (2002) Oligomeric and fibrillar species of amyloid- $\beta$ peptides differentially affect neuronal viability. J Biol Chem 277:32046-32053.

Davis J, Cribbs DH, Cotman CW, Van Nostrand WE (1999) Pathogenic amyloid $\beta$-protein induces apoptosis in cultured human cerebrovascular smooth muscle cells. Amyloid 6:157-164.

Fabian I, Halperin D, Lefter S, Mittelman L, Altstock RT, Seaon O, Tsarfaty I (1999) Alteration of actin organization by jaspamide inhibits ruffling, but not phagocytosis or oxidative burst, in HL-60 cells and human monocytes. Blood 93:3994-4005.

Frandsen A, Schousboe A (1993) Excitatory amino acid-mediated cytotoxicity and calcium homeostasis in cultured neurons. J Neurochem 60:1202-1211.

Furukawa K, Mattson MP (1995) Cytochalasins protect hippocampal neurons against amyloid $\beta$-peptide toxicity: evidence that actin depolymerization suppresses $\mathrm{Ca}^{2+}$ influx. J Neurochem 65:1061-1068.

Furukawa K, Abe Y, Akaike N (1994) Amyloid $\beta$ protein-induced irreversible current in rat cortical neurones. NeuroReport 5:2016-2018.

Furukawa K, Smith-Swintosky VL, Mattson MP (1995) Evidence that actin depolymerization protects hippocampal neurons against excitotoxicity by stabilizing $\left[\mathrm{Ca}^{2+}\right]_{\mathrm{i}}$. Exp Neurol 133:153-163.

Galloway PG, Perry G, Gambetti P (1987) Hirano body filaments contain actin and actin-associated proteins. J Neuropathol Exp Neurol 46:185-199.

Gao ZY, Collins HW, Matschinsky FM, Lee VM, Wolf BA (1998) Cytotoxic effect of $\beta$-amyloid on a human differentiated neuron is not mediated by cytoplasmic $\mathrm{Ca}^{2+}$ accumulation. J Neurochem 70:1394-1400.

Goldberg DJ (1982) Microinjection into an identified axon to study the mechanism of fast axonal transport. Proc Natl Acad Sci USA 79:4818-4822.

Goldberg DJ, Harris DA, Lubit BW, Schwartz JH (1980) Analysis of the mechanism of fast axonal transport by intracellular injection of potentially inhibitory macromolecules: evidence for a possible role of actin filaments. Proc Natl Acad Sci USA 77:7448-7452.

Goldman JE (1983) The association of actin with Hirano bodies. J Neuropathol Exp Neurol 42:146-152.

Gray CW, Patel AJ (1995) Neurodegeneration mediated by glutamate and $\beta$-amyloid peptide: a comparison and possible interaction. Brain Res 691:169-179.

Haass C, Schlossmacher MG, Hung AY, Vigo-Pelfrey C, Mellon A, Ostaszewski BL, Lieberburg I, Koo EH, Schenk D, Teplow DB, Selkoe DJ (1992) Amyloid $\beta$-peptide is produced by cultured cells during normal metabolism. Nature 359:322-325.

Hartley DM, Kurth MC, Bjerkness L, Weiss JH, Choi DW (1993) Glutamate receptor-induced ${ }^{45} \mathrm{Ca}^{2+}$ accumulation in cortical cell culture correlates with subsequent neuronal degeneration. J Neurosci 13:1993-2000.

Hartley DM, Walsh DM, Ye CP, Diehl T, Vasquez S, Vassilev PM, Teplow DB, Selkoe DJ (1999) Protofibrillar intermediates of amyloid $\beta$-protein induce acute electrophysiological changes and progressive neurotoxicity in cortical neurons. J Neurosci 19:8876-8884.

Huang TH, Yang DS, Plaskos NP, Go S, Yip CM, Fraser PE, Chakrabartty A (2000) Structural studies of soluble oligomers of the Alzheimer $\beta$-amyloid peptide. J Mol Biol 297:73-87. 
Isenberg G, Schubert P, Kreutzberg GW (1980) Experimental approach to test the role of actin in axonal transport. Brain Res 194:588-593.

Iwatsubo T, Odaka A, Suzuki N, Mizusawa H, Nukina N, Ihara Y (1994) Visualization of $A \beta 42(43)$ and $A \beta 40$ in senile plaques with end-specific $\mathrm{A} \beta$ monoclonals: evidence that an initially deposited species is A beta 42(43). Neuron 13:45-53.

Joseph R, Han E (1992) Amyloid $\beta$-protein fragment 25-35 causes activation of cytoplasmic calcium in neurons. Biochem Biophys Res Commun 184:1441-1447.

Kasa P, Papp H, Kovacs I, Forgon M, Penke B, Yamaguchi H (2000) Human amyloid- $\beta 1-42$ applied in vivo inhibits the fast axonal transport of proteins in the sciatic nerve of rat. Neurosci Lett 278:117-119.

Kato M, Saito H, Abe K (1997) Nanomolar amyloid $\beta$ protein-induced inhibition of cellular redox activity in cultured astrocytes. J Neurochem 68:1889-1895.

Kawahara M, Kuroda Y (2000) Molecular mechanism of neurodegeneration induced by Alzheimer's $\beta$-amyloid protein: channel formation and disruption of calcium homeostasis. Brain Res Bull 53:389-397.

Kayed R, Head E, Thompson JL, McIntire TM, Milton SC, Cotman CW, Glabe CG (2003) Common structure of soluble amyloid oligomers implies common mechanism of pathogenesis. Science 300:486-489.

Kim HJ, Chae SC, Lee DK, Chromy B, Lee SC, Park YC, Klein WL, Krafft GA, Hong ST (2003) Selective neuronal degeneration induced by soluble oligomeric amyloid beta protein. FASEB J 17:118-120.

Koo EH, Park L, Selkoe DJ (1993) Amyloid $\beta$-protein as a substrate interacts with extracellular matrix to promote neurite outgrowth. Proc Natl Acad Sci USA 90:4748-4752.

Kowall NW (1994) Beta amyloid neurotoxicity and neuronal degeneration in Alzheimer's disease. Neurobiol Aging 15:257-258.

Kuznetsov SA, Langford GM, Weiss DG (1992) Actin-dependent organelle movement in squid axoplasm. Nature 356:722-725.

Lambert MP, Barlow AK, Chromy BA, Edwards C, Freed R, Liosatos M, Morgan TE, Rozovsky I, Trommer B, Viola KL, Wals P, Zhang C, Finch CE, Krafft GA, Klein WL (1998) Diffusible, nonfibrillar ligands derived from $\mathrm{A} \beta_{1-42}$ are potent central nervous system neurotoxins. Proc Natl Acad Sci USA 95:6448-6453.

Lancelot E, Beal MF (1998) Glutamate toxicity in chronic neurodegenerative disease. Prog Brain Res 116:331-347.

Le WD, Colom LV, Xie WJ, Smith RG, Alexianu M, Appel SH (1995) Cell death induced by $\beta$-amyloid 1-40 in MES 23.5 hybrid clone: the role of nitric oxide and NMDA-gated channel activation leading to apoptosis. Brain Res 686:49-60.

Lee E, Shelden EA, Knecht DA (1998) Formation of F-actin aggregates in cells treated with actin stabilizing drugs. Cell Motil Cytoskeleton 39:122-133.

Lee JP, Stimson ER, Ghilardi JR, Mantyh PW, Lu YA, Felix AM, Llanos W, Behbin A, Cummings M, Van Criekinge M, Timms W, Maggio JE (1995) ${ }^{1} \mathrm{H}$ NMR of $\mathrm{A} \beta$ amyloid peptide congeners in water solution. Conformational changes correlate with plaque competence. Biochemistry 34:5191-5200.

Li L, Darden TA, Bartolotti L, Kominos D, Pedersen LG (1999) An atomic model for the pleated $\beta$-sheet structure of $\mathrm{A} \beta$ amyloid protofilaments. Biophys J 76:2871-2878.

Ligon LA, Steward O (2000) Role of microtubules and actin filaments in the movement of mitochondria in the axons and dendrites of cultured hippocampal neurons. J Comp Neurol 427:351-361.

Limbrick Jr DD, Pal S, DeLorenzo RJ (2001) Hippocampal neurons exhibit both persistent $\mathrm{Ca}^{2+}$ influx and impairment of $\mathrm{Ca}^{2+}$ sequestration/extrusion mechanisms following excitotoxic glutamate exposure. Brain Res 894:56-67.

Masliah E (1995) Mechanisms of synaptic dysfunction in Alzheimer's disease. Histol Histopathol 10:509-519.

Masliah E, Terry RD, DeTeresa RM, Hansen LA (1989) Immunohistochemical quantification of the synapse-related protein synaptophysin in Alzheimer disease. Neurosci Lett 103:234-239.

Mattson MP, Cheng B, Davis D, Bryant K, Lieberburg I, Rydel RE (1992) $\beta$-Amyloid peptides destabilize calcium homeostasis and render human cortical neurons vulnerable to excitotoxicity. J Neurosci 12:376-389.

Moretto A, Sabri MI (1988) Progressive deficits in retrograde axon transport precede degeneration of motor axons in acrylamide neuropathy. Brain Res 440:18-24.

Morris RL, Hollenbeck PJ (1995) Axonal transport of mitochondria along microtubules and F-actin in living vertebrate neurons. J Cell Biol 131:1315-1326.

Nagele RG, Kosciuk MC, Hunter ET, Bush KT, Lee H (1988) Immunoelectron microscopic localization of actin in neurites of cultured embryonic chick dorsal root ganglia: actin is a component of granular, microtubuleassociated cross-bridges. Brain Res 474:279-286.

Nemhauser I, Goldberg DJ (1985) Structural effects in axoplasm of DNase I, an actin depolymerizer that blocks fast axonal transport. Brain Res 334:47-58.

Oldenbourg R, Katoh K, Danuser G (2000) Mechanism of lateral movement of filopodia and radial actin bundles across neuronal growth cones. Biophys J 78:1176-1182.

Petkova AT, Ishii Y, Balbach JJ, Antzutkin ON, Leapman RD, Delaglio F, Tycko R (2002) A structural model for Alzheimer's $\beta$-amyloid fibrils based on experimental constraints from solid state NMR. Proc Natl Acad Sci USA 99:16742-16747.

Pike CJ, Walencewicz AJ, Glabe CG, Cotman CW (1991) In vitro aging of $\beta$-amyloid protein causes peptide aggregation and neurotoxicity. Brain Res 563:311-314.

Praprotnik D, Smith MA. Richey PL, Vinters HV, Perry G (1996) Filament heterogeneity within the dystrophic neurites of senile plaques suggests blockage of fast axonal transport in Alzheimer's disease. Acta Neuropathol (Berl) 91:226-235.

Qi JS, Qiao JT (2001) Amyloid $\beta$-protein fragment 31-35 forms ion channels in membrane patches excised from rat hippocampal neurons. Neuroscience 105:845-852.

Richard S, Brion JP, Couck AM, Flament-Durand J (1989) Accumulation of smooth endoplasmic reticulum in Alzheimer's disease: new morphological evidence of axoplasmic flow disturbances. J Submicrosc Cytol Pathol 21:461-467.

Roy S, Coffee P, Smith G, Liem RK, Brady ST, Black MM (2000) Neurofilaments are transported rapidly but intermittently in axons: implications for slow axonal transport. J Neurosci 20:6849-6861.

Sanderson KL, Butler L, Ingram VM (1997) Aggregates of a $\beta$-amyloid peptide are required to induce calcium currents in neuron-like human teratocarcinoma cells: relation to Alzheimer's disease. Brain Res 744:7-14.

Scorziello A, Meucci O, Florio T, Fattore M, Forloni G, Salmona M, Schettini G (1996) $\beta 25-35$ alters calcium homeostasis and induces neurotoxicity in cerebellar granule cells. J Neurochem 66:1995-2003.

Senderowicz AM, Kaur G, Sainz E, Laing C, Inman WD, Rodríguez J, Crews P, Malspeis L, Grever MR, Sausville EA (1995) Jasplakinolide's inhibition of the growth of prostate carcinoma cells in vitro with disruption of the actin cytoskeleton. J Natl Cancer Inst 87:46-51.

Serpell LC (2000) Alzheimer's amyloid fibrils: structure and assembly. Biochim Biophys Acta 1502:16-30.

Song C, Perides G, Wang D, Liu YF (2002) $\beta$-Amyloid peptide induces formation of actin stress fibers through p38 mitogen-activated protein kinase. J Neurochem 83:828-836.

Suzuki K, Terry RD (1967) Fine structural localization of acid phosphatase in senile plaques in Alzheimer's presenile dementia. Acta Neuropathol (Berl) 8:276-284.

Walsh DM, Hartley DM, Kusumoto Y, Fezoui Y, Condron MM, Lomakin A, Benedek GB, Selkoe DJ, Teplow DB (1999) Amyloid $\beta$-protein fibrillogenesis. Structure and biological activity of protofibrillar intermediates. J Biol Chem 274:25945-25952.

Wang L, Ho CL, Sun D, Liem RK, Brown A (2000) Rapid movement of axonal neurofilaments interrupted by prolonged pauses. Nat Cell Biol 2:137-141.

Warita H, Itoyama Y, Abe K (1999) Selective impairment of fast anterograde axonal transport in the peripheral nerves of asymptomatic transgenic mice with a G93A mutant SOD1 gene. Brain Res 819:120-131.

Weiss JH, Pike CJ, Cotman CW (1994) $\mathrm{Ca}^{2+}$ channel blockers attenuate $\beta$-amyloid peptide toxicity to cortical neurons in culture. J Neurochem 62:372-375.

White AR, Guirguis R, Brazier MW, Jobling MF, Hill AF, Beyreuther K, Barrow CJ, Masters CL, Collins SJ, Cappai R (2001) Sublethal concentrations of prion peptide PrP106-126 or the amyloid beta peptide of Alzheimer's disease activates expression of proapoptotic markers in primary cortical neurons. Neurobiol Dis 8:299-316. 
White SR, Williams P, Wojcik KR, Sun S, Hiemstra PS, Rabe KF, Dorscheid DR (2001) Initiation of apoptosis by actin cytoskeletal derangement in human airway epithelial cells. Am J Respir Cell Mol Biol 24:282-294.

Whitson JS, Appel SH (1995) Neurotoxicity of A $\beta$ amyloid protein in vitro is not altered by calcium channel blockade. Neurobiol Aging 16:5-10.

Whitson JS, Glabe CG, Shintani E, Abcar A, Cotman CW (1990) $\beta$-Amyloid protein promotes neuritic branching in hippocampal cultures. Neurosci Lett 110:319-324.

Williamson TL, Cleveland DW (1999) Slowing of axonal transport is a very early event in the toxicity of ALS-linked SOD1 mutants to motor neurons. Nat Neurosci 2:50-56.

Yamada KM, Spooner BS, Wessells NK (1970) Axon growth: roles of microfilaments and microtubules. Proc Natl Acad Sci USA 66:1206-1212.

Yamada KM, Spooner BS, Wessells NK (1971) Ultrastructure and function of growth cones and axons of cultured nerve cells. J Cell Biol 49:614-635.
Yan XZ, Qiao JT, Dou Y, Qiao ZD (1999) $\beta$-amyloid peptide fragment 31-35 induces apoptosis in cultured cortical neurons. Neuroscience 92:177-184.

Yankner BA, Duffy LK, Kirschner DA (1990) Neurotrophic and neurotoxic effects of amyloid $\beta$ protein: reversal by tachykinin neuropeptides. Science 250:279-282.

Yonekawa Y, Harada A, Okada Y, Funakoshi T, Kanai Y, Takei Y, Terada S, Noda T, Hirokawa N (1998) Defect in synaptic vesicle precursor transport and neuronal cell death in KIF1A motor protein-deficient mice. J Cell Biol 141:431-441.

Younkin SG, Goodridge B, Katz J, Lockett G, Nafziger D, Usiak MF, Younkin LH (1986) Molecular forms of acetylcholinesterases in Alzheimer's disease. Fed Proc 45:2982-2988.

Zeng H, Zhang Y, Peng L, Shao H, Menon NK, Yang J, Salomon AR, Freidland RP, Zagorski MG (2001) Nicotine and amyloid formation. Biol Psychiatry 49:248-257. 